\title{
The Effect of Negative and Positive Evidence on Acquisition of Quantifiers by Iranian EFL
}

\author{
Fereshteh Abolhasanpour ${ }^{1} \&$ Ali Akbar Jabbari ${ }^{2}$ \\ ${ }^{1}$ Department of English, Science and Research Branch, Islamic Azad University, Yazd, Iran \\ ${ }^{2}$ Yazd University, Yazd, Iran \\ Correspondence: Ali Akbar Jabbari, Yazd University, Yazd, Iran. E-mail: a_jabbari@hotmail.com
}

\author{
Received: February 13, 2014 Accepted: March 13, 2014 Online Published: March 26, 2014 \\ doi:10.5539/ijel.v4n2p46 \\ URL: http://dx.doi.org/10.5539/ijel.v4n2p46
}

\begin{abstract}
The current study aimed to investigate the role of positive and negative evidence on learning English quantifiers concerning similarities and dissimilarities between the structures of the two languages in the acquisition of English quantifiers. To carry out this study 40 adults lower intermediate EFL learners through OQPT were selected. Participants were divided into experimental and control groups. The experimental group was taught the English quantifiers through negative evidence while the control group though positive evidence. Two tests namely Grammaticality Judgment Task (GJT) and Translation Task (TT) were administered in three sessions as a pretest, immediate post-test and delayed post-test. The results of the immediate post-test showed that the experimental group outperformed, especially in TT. On the other hand, the control group performed on the two tasks in the same form with no significant difference. In the delayed post-test, the results of the immediate post-test repeated. These results suggest that negative evidence was highly effective in short-term and long-term period and facilitates the phase of the acquisition of the foreign language, namely English quantifiers in the absence of naturalistic input. Furthermore, the effect of negative evidence was significantly higher than L1 transfer.
\end{abstract}

Keywords: quantifiers, negative and positive evidence, long and short-term effects, learnability problems

\section{Introduction}

Any theory of language learning has to acknowledge the role that input plays in the process of second language learning (SLA) and the benefit of the interaction between participants in the classroom.

According to Long (1996), there are two types of input in SLA: positive evidence and negative evidence. Positive evidence is a kind input that learners receive concerning the target language itself in a natural linguistic environment. It can be provided as authentic input, like what occurs in naturalistic conventions, or as modified input, like what occurs in foreigner talk discourse or teacher talk (Chaudron, 1988). It consists of descriptive information about a form or an utterance. It comprises actually occurring sequences, i.e., sentences of the language. Various options exist for positive evidence including plentiful exemplars of the target feature without any device to draw attention to it. In contrast, negative evidence provides information about what is not possible in the target language (Long, 1996; White, 1990). It consists of information about the impossibility and ungrammaticality of a form or an utterance. It includes explanation, expansion, explicit grammar teaching and correction of wrong sequences or ungrammatical sentences.

\subsection{Negative and Positive Evidence}

Approximately all EFL teachers agree with the importance of negative and positive input in the classrooms, but there might be disagreements on the type of input that should be provided in the classrooms. Hence inspired by this challenge, and realizing that no such researches have been undertaken thus far to address this problem in Iranian context, the researcher intended to explore and observe the effects of negative and positive evidence and learnability problems in teaching English quantifiers that teachers provide for Iranian learners at different classes. The researcher was interested to find out the above-mentioned relationship because the results of this study may be helpful in EFL domain. Since sometimes provision of using only one the evidence, which is not proportionate with learners' need may have a hindering effect on their language learning development.

For decades, on the theoretical front, the form and type of input in learning second language is still a 
controversial issue. Those promoting the nativist position of acquisition support the idea that language acquisition is made possible by Universal Grammar (UG), "the system of principles, conditions, and rules that are elements or properties of all human languages" (Chomsky, 1975, p. 29). They declare that the innate human linguistic mechanism causes the formation and restructuring of second language grammars and it functions in cycle with positive evidence. (Cook, 1991; Schwartz, 1993). Accordingly, in this view, positive evidence is all and it is required for acquisition to happen (Chomsky, 1968), however negative evidence only affects the performance but not change in underlying competence (Schwartz, 1993).

Later, Krashen $(1982,1985)$ by Input Hypothesis rejects the usefulness of negative evidence on SLA and reveals that negative evidence interrupts the flow of discourse for providing comprehensible input. But, many researchers have been challenged these disputation and mention that, L2 learning cannot be effected by exposure to positive input alone, even if the input is comprehensible (e.g., Bley-Vroman, 1989; Harley, 1989; Swain, 1985).

Swain $(1985,1995)$ in her Output Hypothesis emphasizes in the importance of output opportunities in L2 development and asserts that comprehensible input is necessary but insufficient for learners' L2 development. Based on a number of studies on French Immersion (Harley, 1989; Swain, 1985), she declares that learners were far from native-like performance whereas they received a great deal of comprehensible input. She also attributes considerable importance to negative evidence, in effect considering the shortages in learner performance on its absence in the immersion classrooms.

Schmidt $(1990,1995,2001)$ in his Noticing Hypothesis claims that noticing is requisite for learning and learners must consciously pay attention to input in order to learn the SL.

Also Ellis (1991), Gass and Varonis (1994) and Schmidt (1990, 1995, 2001) subscribe the Noticing Hypothesis. They recognize the value of negative evidence and allocate a facilitative role for negative evidence in drawing learner attention to form. Based in their perspective, it triggers learners to recognize the gap between their IL and the target norm and this process in turn leads to subsequent grammatical restructuring.

In addition, interactionists see positive evidence as insufficient and propose a role for both positive and negative evidence (Labov, 1969) and hold the idea that social context of language and other persons with whom a person interacts influence language acquisition. Long (1996), in his updated Interaction Hypothesis, suggests that negative evidence provides direct and indirect information about what is grammatical. As stated by him, "negotiation for meaning, and especially negotiation work that triggers interactional adjustments by the NS or more competent interlocutor" facilitates L2 development since it "connects input, internal learner capacities, particularly selective attention, and output in productive ways" (Long, 1996, pp. 451-452).

Making errors or incorrect generalizations is a natural part of mastering a new language by foreign language learners. The errors can be of different kinds, for example syntax, pronunciation or word choice errors. In syntactic process acquisition of the English quantifier is one of the biggest challenges for L2 learners, especially for the learners whose native language has a different parameter.

\subsection{Quantifiers in English and Persian}

In English quantifiers precede and modify nouns and must be syntactically agree with the noun. "The distinction between count nouns and mass nouns is determined by the quantifiers and the determiners that are appropriate to the nouns" (Ware, 1979, p. 15). Some quantifiers are used with countable nouns (a few friends), some of them are used with uncountable nouns (a large amount of sugar) and the last type used with either countable nouns or uncountable nouns (a lot of money, a lot of papers).

While quantifier choice in Persian is highly complicated. In Persian, numbers of the quantifiers that distinguish count vs. mass nouns are fewer than in English. E.g., "čcend-ta ketab" (some book s $_{\mathrm{s}}$ used with countable nouns and (ye zcerre næemcek) used with uncountable nouns. Shaghaghi (2002) mentioned in Persian "tedâdi" and "meghdâri" have the same meaning but the former used for countable nouns and the latter use for uncountable nouns, e.g., "tedâdi ketâb" (number of books), "meghdâri âb" (a little water). But a large number of them can be used with countable or countable nouns "hich", "ceslcen", "cebcedcen", "behichvoejeh (no and any).

Moreover, opposite to English in Persian some quantifiers precede and some of them follow nouns.
a. "čcendin dâneshjo"
b. "Howeye tælæffozhâ"

(Some student $\mathrm{s}_{\mathrm{s}}$ )

(All of the pronunciations) 
c. "Meghdâre ziâdi ghæhveh"

d. "âvâhâye bishtceri"

e. "Dâneshe bishtceri/bishomâri"

f. "ævamele ziâdi"
(Too much coffee)

(Many sounds)

(Much knowledge)

(A large number of factors)

As mentioned above, there are varieties of quantifiers in English and Persian, but in this study the focus will just be on thirteen English quantifiers including "some, no, any, none of, a large number of, a large amount of, much, many, too much, too many, a few, a little and a lot of" and based on their translation into Persian and by juxtaposition of English and Persian quantifiers they are classified into five contexts enumerated below.

\subsubsection{Context One: Persian and English Simple Pre-Quantifiers}

\section{A) Negative Quantifiers in English and Persian}

Negative quantifiers indicate the negation of any amount or quantity of nouns. Some examples of Persian and English negative quantifiers are as follows:

(a) Persian: "Hich”, “æslæn”, “æbædæn”, "Behichvæjeh” and "Hær” vs. English "No” and “Any”

- "Hich": If the quantifier is in negative form, the verb is also negated

(2)

a. Hich medâdi nædâræm.

(Any pencil do not have)

"I have got no pencils"

Mahootian (1997, p. 78) mentioned "Hich" could be used with some arguments such as "Goneh" (kind), "noe" (sort) or "kodam" (one) (see example b).

b. Hich goneh medâdi nægereftæm.

(Any kind pencil did not get)

"I did not get any kind of pencils"

- "Hær" is used in two ways:

- To show uncertain number of one or some things. In this form it means "any" (see example c).

(3)

a. Age hær kodom æz dostât ælâghemændænd mâ râ mottæle kon.

(If any one of friend your interested us $+\mathrm{EZ}$ inform do)

If any of your friends are interested, let us know.

- To show inclusiveness

b. Hær do medâdi râ khæridam: (hær do medâdi.)

(Each two pencils+EZ bought-I)

I bought each two pencils.

"Har" can be applied to make compound nouns such as "Hær kojâ" (everywhere), "Hær yek" (each one), "Hær goneh" (each kind), "Hær ædæd" (each number); also they are dependent on the noun.

c. Hær goneh ketâb.

\section{(Each kind book)}

"Each kind of book"

B) English Quantifier "Some" vs. Persian "Chænd"

(a) Persian: "Chænd", "Chændin", "Chændta", "Meghdâri”, "Eddei”, "Tedâdi”, "Bærkhi”, "Bæzi(æz)", "Pâreei”" and "Ghædri" show the ambiguous number or amount of some things (see example 4).

(4)

a. Chændin medâd cherâ khæridi? 
(Some pencil why bought)

"Why did you buy several pencils?"

Mahootian (1997) mentioned that among these quantifiers most of them are used with countable nouns. For example, "Edde-I" is used with countable human nouns and "Meqdâri" is only applied with uncountable nouns (see $\mathrm{b}$ and $\mathrm{c}$ ).

b. Edde-I æz moællemhâ

(Some-IND from reacher-PL)

"Some of the teachers"

c. Meqdâr-I æz pænir

(Some-IND from cheese)

"Some of the cheese"

Mahootian (1997) added "Chænd-ta", "Eddei", "Meqdâri” and "Chaænd ædæd" become nonpartitive when used without "æz" or as the plural marker on the NP (see d, e and f).

d. Chand-tâ medâd

(A number of pencil)

"Some pencils"

e. Edde-I moællem

(Some-IND teacher)

"Some teachers"

f. Meqdâr-I pænir

(Some-IND cheese)

"Some cheese"

When "Bæzi" is used nonpartitively it is restricted to nonspecific references.

(5) Bæzi mærdom hichvæqt râzi nist-and

(Some people never satisfied NEG.be-3P)

"Some people are never satisfied."

"Chænd" also means "a few", but "a few" is under the category of phrasal quantifiers so the explanation is provided in English phrasal quantifiers. 
Table 1. Persian and English simple pre-quantifiers

\begin{tabular}{|c|c|c|c|}
\hline Equivalent structure in Persian & $\begin{array}{l}\text { Ways of } \\
\text { simulation in } \\
\text { Persian }\end{array}$ & Explanation & Examples \\
\hline \multirow[t]{2}{*}{ 1) Simple pre-quantifiers } & $\begin{array}{l}\text { 1) Chændin } \\
\text { dâneshjo }\end{array}$ & $\begin{array}{l}\text { 1) Without "I" Ezafe } \\
\text { between quantifier and } \\
\text { noun }\end{array}$ & $\begin{array}{l}\text { 1) Some } \\
\text { students }\end{array}$ \\
\hline & 2) Meghdâri pænir & $\begin{array}{l}\text { 2) Without "I" Ezafe } \\
\text { between quantifier and } \\
\text { noun }\end{array}$ & $\begin{array}{l}\text { 2) Some } \\
\text { cheeses }\end{array}$ \\
\hline \multirow[t]{2}{*}{$\begin{array}{l}\text { 2) Simple pre-quantifiers with } \\
\text { indefinite ye after noun or after } \\
\text { adjective argument and its pre-nominal }\end{array}$} & 1) Hich færdi & $\begin{array}{l}\text { 1) Without "I" Ezafe } \\
\text { between quantifier and } \\
\text { noun }\end{array}$ & 1) No subject \\
\hline & $\begin{array}{l}\text { 2) Hich ertebâte } \\
\text { tæbiee }\end{array}$ & $\begin{array}{l}\text { 2) Without "I" Ezafe } \\
\text { between quantifier and } \\
\text { noun }\end{array}$ & $\begin{array}{l}\text { 2) No natural } \\
\text { connections }\end{array}$ \\
\hline \multirow[t]{2}{*}{$\begin{array}{l}\text { 3) Simple pre-quantifiers with plural } \\
\text { simulation of morpheme in head noun }\end{array}$} & $\begin{array}{l}\text { 1) Bærkhi/bæzi } \\
\text { nevisændegân }\end{array}$ & $\begin{array}{l}\text { 1) With "I" Ezafe } \\
\text { between quantifier and } \\
\text { noun }\end{array}$ & $\begin{array}{l}\text { 1) Some } \\
\text { authors }\end{array}$ \\
\hline & $\begin{array}{l}\text { 2) Hæmeye } \\
\text { mætenhâ }\end{array}$ & $\begin{array}{l}\text { 2) With "I" Ezafe } \\
\text { between quantifier and } \\
\text { noun }\end{array}$ & 2) All texts \\
\hline \multirow{5}{*}{$\begin{array}{l}\text { 4) With zero simulation of indefinite } \\
\text { ye after noun or after adjective } \\
\text { argument and its pre-nominal }\end{array}$} & 1) moddæti & & 1) Some time \\
\hline & 2) Khætti & & 2) Any line \\
\hline & 3) Zæni & & 3) Any woman \\
\hline & 4) Pætoei & & 4) No blanket \\
\hline & $\begin{array}{l}\text { 5) Jænbeye } \\
\text { asheghanei }\end{array}$ & & $\begin{array}{l}\text { 5) No romantic } \\
\text { aspects }\end{array}$ \\
\hline \multirow{2}{*}{$\begin{array}{l}\text { 5) With zero simulation of } \\
\text { pre-quantifier and appearance of plural } \\
\text { morpheme in nominal argument and } \\
\text { indefinite ye }\end{array}$} & 1) Pishnehaddaei & & $\begin{array}{l}\text { 1) Some } \\
\text { suggestions }\end{array}$ \\
\hline & 2) Porseshhaei & & $\begin{array}{l}\text { 2) Some } \\
\text { questions }\end{array}$ \\
\hline
\end{tabular}

\subsubsection{Context Two: Persian Simple Post-Quantifiers vs. English Simple Pre-Quantifiers}

Amokhteh (1997, p. 21) states that "indefinite ye" is used when we are using Persian simple post- quantifiers as equivalent structures for English simple quantifiers. Except one form, we should use "indefinite ye" in all the structures, after nouns and after adjective arguments or noun subordinate.

In addition, in these structures countable and definite nouns are used with plural morphemes.

(a) Persian "Færâvani", "Besyari" vs. "Many" and "Much"

We use "Besyâr, Besyari, Færâvani and Bishomâri" with countable and uncountable nouns.

(6) Ghæzaye besyari khordam

(food many I ate)

"I ate many food." 
Table 2. Persian simple post-quantifiers as equivalent structures for English simple quantifiers

\begin{tabular}{|c|c|c|c|}
\hline $\begin{array}{l}\text { Ways of simulation in } \\
\text { Persian }\end{array}$ & $\begin{array}{l}\text { Equivalent structure } \\
\text { in Persian }\end{array}$ & Explanation & Examples \\
\hline $\begin{array}{l}\text { 1) Dâneshe } \\
\text { bishtæri/bishomâri }\end{array}$ & $\begin{array}{l}\text { Persian post simple } \\
\text { quantifiers with } \\
\text { "indefinite ye" after } \\
\text { the last subordinate } \\
\text { argument }\end{array}$ & $\begin{array}{l}\text { With "I" Ezafe } \\
\text { between noun and } \\
\text { post-quantifier }\end{array}$ & $\begin{array}{l}\text { 1) Much } \\
\text { knowledge }\end{array}$ \\
\hline 1) âvâhâye bishtæri & $\begin{array}{l}\text { Persian post simple } \\
\text { quantifiers with } \\
\text { plural morpheme } \\
\text { after noun and } \\
\text { "indefinite ye" after } \\
\text { the last subordinate } \\
\text { argument of noun }\end{array}$ & $\begin{array}{l}\text { With "I" Ezafe } \\
\text { between noun and } \\
\text { post-quantifier }\end{array}$ & $\begin{array}{l}\text { 1) Many } \\
\text { sounds }\end{array}$ \\
\hline 1) Shekæri færâvân & $\begin{array}{l}\text { Persian post simple } \\
\text { quantifiers with } \\
\text { "indefinite ye" after } \\
\text { noun }\end{array}$ & $\begin{array}{l}\text { Without "I" Ezafe } \\
\text { between noun and } \\
\text { post-quantifier }\end{array}$ & 1) Much sugar \\
\hline $\begin{array}{l}\text { 1) Mævâredi besyâr } \\
\text { 2) Sâkhtârhâei chænd }\end{array}$ & $\begin{array}{l}\text { Persian post simple } \\
\text { quantifiers with } \\
\text { plural morpheme } \\
\text { after noun and } \\
\text { "indefinite ye" }\end{array}$ & $\begin{array}{l}\text { Without "I" Ezafe } \\
\text { between noun and } \\
\text { post-quantifier }\end{array}$ & $\begin{array}{l}\text { 1) Many cases } \\
\text { 2) Many } \\
\text { structures }\end{array}$ \\
\hline \multirow[t]{2}{*}{$\begin{array}{l}\text { 1) Tælâshi færâvan } \\
\text { 2) Tæsaviri besyâr } \\
\text { 3) Nætayeji besyâr }\end{array}$} & \multirow[t]{2}{*}{$\begin{array}{l}\text { Persian post simple } \\
\text { quantifiers without } \\
\text { "indefinite ye" }\end{array}$} & \multirow[t]{2}{*}{$\begin{array}{l}\text { With "I" Ezafe } \\
\text { between noun and } \\
\text { post-quantifier }\end{array}$} & $\begin{array}{l}\text { 1) Much effort } \\
\text { 2) Many } \\
\text { figures }\end{array}$ \\
\hline & & & $\begin{array}{l}\text { 3) Many } \\
\text { advantages }\end{array}$ \\
\hline
\end{tabular}

\subsubsection{Context Three: Persian Compound Quantifiers vs. English Simple Pre-Quantifiers}

(a) Persian compound quantifiers vs. "Too much" and "Too many"

Sometimes Persian compound quantifiers will be appeared in the form of pre or post/subordinate argument as an equivalent form for English simple quantifiers. We have two forms of compound quantifiers in Persian:

- Noun can be formulated with lexical simulation such as "Tedâd" (number), "Edeh" (some), "Goroh" (group), "Meghdâr" (some), "Bækhsh" (part) and "Ghesmæt" (part/piece) with the addition of one quantifier such as "Kæm, Besyâr, Andæk, Bishomâr, æzam, Omdeh", which is simulated with "I" Ezafe between these two word. These kinds of Persian compound quantifiers before head nouns have been classified under the sub category of pre-quantifiers.

- We can consider this kind of compound quantifier, as a pre-quantifier just by adding one Ezafe and the only Ezafe that we can use in this structure, is "æz". The general structure will be articulated by [noun + "I" Ezafe $+($ adverb $)+$ quantifier + indefinite ye + "æz" Ezafe]. The preceding structure is a compound quantifier, which can be performed with head noun or other noun's pre argument Amokhteh (2006, p. 24). Sometimes we subtract the noun so its structure can be [(adverb) + quantifier + indefinite ye + "æz" Ezafe].

Mahootian (1997) indicates quantifiers such as "Meghdâri æz", "Tæmâme", "Hæmeye" cause the simulation of plural symbols and the words "Hær" (every) and "Hich" (nothing) are used to create quantifier compounds: "Hærkodum" (either/any one of a group), "Hichkodum" (neither/none), "Hær-do" (Bothe), "Hishki/hich kæs" (no one), "Hærja" (anywhere), "Hæmeja” (everywhere), "Hærkæs" (anyone), "Hærvæght" (anytime). 
Table 3. Persian compound quantifiers vs. English simple pre-quantifiers

\begin{tabular}{|c|c|c|c|}
\hline $\begin{array}{l}\text { Equivalent structure } \\
\text { in Persian }\end{array}$ & $\begin{array}{l}\text { Ways of simulation } \\
\text { in Persian }\end{array}$ & Explanation & Examples \\
\hline $\begin{array}{l}\text { 2) Tedâde besyâr } \\
\text { ziâdi/tedâde bi } \\
\text { shomâri æks }\end{array}$ & $\begin{array}{l}\text { Pre compound } \\
\text { quantifier without } \\
\text { "I" Ezafe and } \\
\text { "indefinite ye" at } \\
\text { the end of the } \\
\text { quantifier }\end{array}$ & $\begin{array}{l}\text { "I" Ezafe does not } \\
\text { simulate between } \\
\text { compound } \\
\text { quantifier and head } \\
\text { noun. Also nouns } \\
\text { appear without } \\
\text { plural morpheme }\end{array}$ & $\begin{array}{l}\text { 2) Too many } \\
\text { pictures }\end{array}$ \\
\hline $\begin{array}{l}\text { 1) Bækhshe æzæmi } \\
\text { zæban shenâs }\end{array}$ & $\begin{array}{l}\text { Pre compound } \\
\text { quantifier without } \\
\text { "I" Ezafe and } \\
\text { "indefinite ye" at } \\
\text { the end of the } \\
\text { quantifier }\end{array}$ & $\begin{array}{l}\text { There is a "I" Ezade } \\
\text { between compound } \\
\text { quantifier and head } \\
\text { noun and countable } \\
\text { head nouns appear } \\
\text { with plural } \\
\text { morpheme }\end{array}$ & 1) Most linguistics \\
\hline $\begin{array}{l}\text { 1) Tedâde ziâdi æz } \\
\text { zaæbân shenâsân } \\
\text { 2) Tedâde } \\
\text { ziâdi/besyâri æz } \\
\text { mænâbeh } \\
\text { 3) Meghdâr besyâr } \\
\text { ziâdi (æz) âb }\end{array}$ & $\begin{array}{l}\text { Pre compound } \\
\text { quantifier with } \\
\text { Ezafe "az" and } \\
\text { "indefinite ye" at } \\
\text { the end of the } \\
\text { quantifier }\end{array}$ & $\begin{array}{l}\text { "I" Ezade does not } \\
\text { simulate between } \\
\text { compound } \\
\text { quantifier and head } \\
\text { noun }\end{array}$ & $\begin{array}{l}\text { 2) Too many } \\
\text { references }\end{array}$ \\
\hline
\end{tabular}

1.2.4 Context Four: Persian Pre-Quantifiers vs. English Phrasal Quantifiers

A) English Phrasal Quantifiers

According to Swan (1995, p. 319) the expressions a lot, lots, plenty, a great deal, a large number and the majority have similar meaning to much, many and most but the grammar is not quite the same. In particular, of is used after these expressions even before nouns with no determiner. Some examples are provided below.

(7)

a. There is not a lot of meat left.

b. Plenty of shops open on Sunday mornings.

B) Persian simple pre-quantifier with "indefinite ye" after quantifier and without "I" Ezafe between quantifier and head noun:

(8) Kæmi soup meil dârid?

(A little soup would you like?)

"Would you like a little soup?"

C) Persian simple pre-quantifier with head noun in the composition with plural morpheme and "I" Ezafe between quantifier and head noun:

(9) Hæmeye tælæffozhâ sæhih hæstænd.

(All of the pronunciations correct are)

"All of the pronunciations are correct."

D) Persian simple pre-quantifier with "indefinite ye" after head noun or adjective argument or subordinate noun and without "I" Ezafe between quantifier and head noun:

(10) Chænd ketâbe târikhi

(A few books histitical...) 
"A few historical books..."

E) Persian simple pre-quantifiers with indefinite ye without "I" Ezafe between quantifier and noun.

(11) Shoma bâyæd kæmi ghænd ezâfe konid

(You must a little sugar add)

"You must add a little sugar..."

\subsubsection{Context Five: Persian Compound/Post Quantifiers vs. English Phrasal Quantifiers}

Persian compound quantifiers contain a quantifier and a noun complement; however, in a post quantifier the quantifier is right headed and its complement happens at initial position. English phrasal quantifier forms a maximal projection with the head of a phrasal quantifier, e.g., "a lot" and a prepositional phrase as its complement. Amokhteh (2006, p. 28) states that Persian simple pre-quantifier; simple post-quantifier, pre-compound quantifier and post-compound quantifiers can be used as equivalent forms in English for phrasal quantifiers. Some examples are provided as follows:

A) Persian simple post-quantifier with "indefinite ye" and "I" Ezafe between head noun (or noun and adjective argument) and quantifier:

a. ævamele ziâdi

A large number of factors...

b. æjale nækon. Væghet ziâdi dârim.

(Do not rush, time a large amount of there is)

"Do not rush, there is a large amount of time."

B) Persian simple post-quantifier with "indefinite ye" at the end of head noun and with "I" Ezafe between quantifier and head noun:

a. Nætâyeje færâvân

A great number of advantages...

b. Lebâshâye besyâr

A large amount of clothing...

C) Persian post-quantifier without "indefinite ye" but with "I" Ezafe between head noun and post-quantifier:

(14) Dâneshmændâne besyâr

A lot of scientists...

D) Persian compound pre-quantifier without "I" Ezafe and with "indefinite ye" at the end of quantifier without simulation of "I" Ezafe between pre-quantifier and head noun:

(15) Tedâde ziâdi sorkhpost

A large number of Native Americans...

E) Persian compound pre-quantifier without "indefinite ye" and with "I" Ezafe between compound pre-quantifier and head noun:

a. Bækhshe omdeye poul

Much of money...

b. Romænhâ ghesmæte æzæme Engelestan râ fæteh kærænd.

(The Romans most of England conquered)

"The Romans conquered most of England."

F) Persian compound pre-quantifier with (simulation of "æz" Ezafe) and "indefinite ye" at the end of last word of compound pre-quantifier and before Ezafe and without simulation of "I" Ezafe between Ezafe and noun: 
(17)

a. Tedâde ziâdi æz hædâyâye dostâneh...

(A lot of gifts friendly)

"A lot of friendly gifts..."

b. Meghdâre besyâr ziâdi chobe khoshk

(A good number of woods dry)

"A good number of dry woods..."

The above account of quantifiers' formation in English and Persian highlights marked parametric differences and similarities between the two languages. As for English all the quantifiers precede nouns but in Persian some quantifiers precede and some of them follow nouns. Concerning the formation of quantifiers in these languages, English is different from Persian in this syntactical point.

\subsection{Learnability and Parameter Resetting in L2 Acquisition}

Nowadays many researchers in order to justify the L2 learnability problems focus on the nature of the triggering data in SLA. Mostly, L2 learners are not exposed to the same kind of input as L1 learners. Even though they are confronting with other students' incorrect and unnatural utterances, they reflect the positive evidence as a more formal form that is regularly different in nature. Negative evidence may also be available in the form of correction and certain kinds of grammar teaching.

The question arises as to whether the different kinds of input available in SLA are in fact appropriate for triggering principles and parameters, and whether L1 (Persian) place a role in the acquisition of L2 (English) or properties of L1 transfer to L2. As stated by White (1991) in order to arrive at the appropriate L2 grammatical forms just relying on positive evidence cannot be enough for L2 learners. Namely to reset the L2 word order, negative evidence provides enough information, which is not always accessible through positive evidence.

In the present study the insights from above mentioned issues were used to view the effects of positive and negative evidence in short-term and long-term period in the acquisition of English quantifiers from a new perspective. Since context one is similar in two languages, but other four contexts are not. This means that in context one both Persian and English have the same structure as pre-quantifier. In contrast, in other four contexts both structures are dissimilar in two languages. E.g., context two is simple post-quantifier in Persian; while in English it is simple pre-quantifier. Therefore, the current study endeavored to investigate whether similarities and dissimilarities between the structures of two languages might affect the acquisition of English quantifiers. Also the participants who received the negative input have a better understanding of English quantifiers. In this way, the role of L1 structures in the acquisition of English quantifiers constituted another purpose of the study.

\section{Research Hypotheses}

This study intended to address the following research Hypotheses:

1) There is no relationship between positive and negative input in the acquisition of English quantifiers by Iranian EFL learners.

2) There is no difference between positive and negative input in short and long-term period.

3) There is no difference between positive and negative input in the acquisition of English quantifiers through Persian and English simple pre-quantifiers.

4) There is no difference between positive and negative input in the acquisition of English quantifiers through Persian simple post-quantifiers and English pre-quantifiers.

5) There is no difference between positive and negative input in the acquisition of English quantifiers through Persian compound quantifiers and English simple quantifiers.

6) There is no difference between positive and negative input in the acquisition of English quantifiers through Persian pre-quantifiers and English phrasal quantifiers.

7) There is no difference between positive and negative input in the acquisition of English quantifiers through Persian compound/post quantifiers and English phrasal quantifiers.

\section{Method}

\subsection{Participants}

Forty adults lower intermediate EFL learners (21 females and 19 males) participated in this experiment. They 
were selected among a pool of 100 ones from institute students who took part in this study. The leaners' ages ranged from 20 to 31 . They were divided into two groups and for each group, 20 students who were almost at the same level of proficiency were selected as participants.

\subsection{Instruments}

First of all in order to determine the proficiency levels of the subjects, the Oxford Quick Placement Test (OQPT) (2001) was administrated. Also, two tasks including Grammaticality Judgment Task (GJT) and Translation Task (TT), successively to test comprehension and production of quantifiers of learners were used. In each task, thirteen English quantifiers were included. The items of two tasks were extracted from Swan (1995) and Raymond Murphy (2012).

In the GJT task, 50 randomly ordered sentences were presented to the subjects using a Likert scale and in TT 26 Persian sentences included and in every case the students had to translate the items into English using appropriate quantifiers.

\subsection{Procedures}

The current study followed a cross-sectional, experimental and quantitative method in which Iranian EFL learners were stratified randomly. In this study a pre-test, immediate and delayed post-tests with two different treatments for experimental and control groups were conducted. In order to find out the homogenous groups Oxford Quick Placement Test (OQPT) was administrated to 100 subjects. Later 40 selected students were divided in to experimental and control groups.

Before the treatment, both groups were subjected to a pre-test with Grammatically judgment test and Translation test to ensure the level of proficiency in quantifiers. After the administration of the pre-test, the English quantifiers were taught to the subjects in different ways. The experimental group was taught through providing negative evidence. Some grammatical explanations were given, e.g., in English "many" is a pre-quantifier while in Persian it is a post-quantifier. Error correction was utilized; i.e., whenever a subject made a mistake in this case, she/he was told that in English they would never say this quantifier in that form. The control group was taught the same structure through providing just positive evidence; e.g., cartoons, songs, stories, film without providing any explanations about quantifiers. Participants were not aware of the purpose of the treatment, nor did they know what differences there were between the instructional procedures of two groups.

Right after the instruction, both groups were given an immediate post-test by using the randomly changed questionnaires of pre-test in two tasks. These tests were then re-administered about 2 weeks later, as a delayed post-test to test the long-term effect of the negative and positive evidence. The two types of the test, which were re-administered to all subjects in both groups, were similar with a rather different order but identical in nature. All of the tests were given during the class periods as part of normal instruction activities.

\section{Results}

As a means to examine the effects of negative and positive input on learning English as a foreign language by Persian speakers, sequences of Independent Samples T-test were presented. Also the means of the test scores were used to show the comparison between the performance of the participants in two groups.

\subsection{Pre-Test Scores}

In order to find out whether or not the subjects selected for this study are homogeneous in these criteria they were subjected to a pretest prior to the treatment. 
Table 4. Descriptive statistics of pre-test in GJT for both groups

\begin{tabular}{llccc}
\hline & Group & Mean & Std. Deviation & N \\
\hline \multirow{2}{*}{ Persian and English Simple } & Experimental & 42.91 & 10.90 & 20 \\
Pre-Quantifiers & Control & 40.83 & 10.43 & 20 \\
& Total & 41.87 & 10.58 & 40 \\
Persian Simple Post-Quantifiers & Experimental & 54.37 & 17.80 & 20 \\
vs. English Simple & Control & 51.87 & 11.66 & 20 \\
Pre-Quantifiers & Total & 53.12 & 14.91 & 40 \\
Persian Compound Quantifiers & Experimental & 38.75 & 18.97 & 20 \\
vs. English Simple & Control & 31.25 & 11.10 & 20 \\
Pre-Quantifiers & Total & 35.00 & 15.81 & 40 \\
& Experimental & 25.00 & 15.70 & 20 \\
Persian Pre-Quantifiers vs. & Control & 31.25 & 13.14 & 20 \\
English Phrasal Quantifiers & Total & 28.12 & 14.64 & 40 \\
Persian Compound/Post & Experimental & 32.18 & 9.57 & 20 \\
Quantifiers vs. English Phrasal & Control & 37.50 & 13.75 & 20 \\
Quantifiers & Total & 34.84 & 12.00 & 40 \\
\hline
\end{tabular}

Table 5. Descriptive statistics of pre-test in TT for both groups

\begin{tabular}{llccc}
\hline & Group & Mean & Std. Deviation & $\mathrm{N}$ \\
\hline Persian and English & Experimental & 40.83 & 17.50 & 20 \\
Simple Pre-Quantifiers & Control & 41.66 & 13.78 & 20 \\
& Total & 41.25 & 15.55 & 40 \\
Persian Simple & Experimental & 43.75 & 22.76 & 20 \\
Post-Quantifiers vs. & Control & 37.50 & 23.64 & 20 \\
English Simple & Total & 40.62 & 23.12 & 40 \\
Pre-Quantifiers & Experimental & 45.00 & 22.36 & 20 \\
Persian Compound & Control & 46.25 & 20.31 & 20 \\
Quantifiers vs. English & Total & 45.62 & 21.09 & 40 \\
Simple Pre-Quantifiers & 46.25 & 21.87 & 20 \\
Persian Pre-Quantifiers & Experimental & 47.50 & 19.70 & 20 \\
vs. English Phrasal & Control & 46.78 & 20.55 & 40 \\
Quantifiers & Total & 42.50 & 14.28 & 20 \\
Persian Compound/Post & Experimental & 41.87 & 12.35 & 20 \\
Quantifiers vs. English & Control & 42.18 & 13.18 & 40 \\
Phrasal Quantifiers & Total & & &
\end{tabular}

The comparison of mean scores of two groups in each task revealed that experimental and control groups were approximately parallel in all contexts so it indicated that the two groups were in the similar levels. Additionally, it ensured that the participants met the researcher's criteria for subject selection. In other words, the two selected groups could be considered similar in terms of their knowledge of English quantifiers. Descriptive results of pretest for two groups are displayed in Tables 4 and 5.

\subsection{Immediate Post-Test Scores}

So as to test the short-term effect of negative and positive evidence and to analysis the questions in this study post-test one was administrated. 
Table 6. Descriptive statistics of immediate post-test in GJT for both groups

\begin{tabular}{llccc}
\hline & Group & Mean & Std. Deviation & N \\
\hline \multirow{2}{*}{ Persian and English Simple } & Experimental & 76.25 & 16.05 & 20 \\
Pre-Quantifiers & Control & 48.75 & 10.90 & 20 \\
& Total & 62.50 & 19.42 & 40 \\
Persian Simple & Experimental & 89.37 & 10.93 & 20 \\
Post-Quantifiers vs. English & Control & 71.87 & 12.08 & 20 \\
Simple Pre-Quantifiers & Total & 80.62 & 14.41 & 40 \\
Persian Compound & Experimental & 73.75 & 16.17 & 20 \\
Quantifiers vs. English Simple & Control & 41.25 & 12.23 & 20 \\
Pre-Quantifiers & Total & 57.50 & 21.70 & 40 \\
& Experimental & 78.12 & 15.10 & 20 \\
Persian Pre-Quantifiers vs. & Control & 59.37 & 12.74 & 20 \\
English Phrasal Quantifiers & Total & 68.75 & 16.74 & 40 \\
& Experimental & 78.43 & 8.71 & 20 \\
Persian Compound/Post & Control & 49.37 & 14.32 & 20 \\
Quantifiers vs. English & Total & 63.90 & 18.80 & 40 \\
\hline Phrasal Quantifiers & & & & \\
\hline
\end{tabular}

Table 7. Descriptive statistics of immediate post-test in TT for both groups

\begin{tabular}{llccc}
\hline & Group & Mean & Std. Deviation & N \\
\hline Persian and English Simple & Experimental & 93.33 & 9.97 & 20 \\
Pre-Quantifiers & Control & 48.33 & 21.56 & 20 \\
& Total & 70.83 & 28.18 & 40 \\
Persian Simple Post-Quantifiers & Experimental & 93.75 & 15.96 & 20 \\
vs. English Simple & Control & 61.25 & 17.15 & 20 \\
Pre-Quantifiers & Total & 77.50 & 23.20 & 40 \\
& Experimental & 83.75 & 14.67 & 20 \\
Persian Compound Quantifiers & Control & 41.25 & 23.33 & 20 \\
vs. English Simple & Total & 62.50 & 28.86 & 40 \\
Pre-Quantifiers & Experimental & 95.00 & 10.25 & 20 \\
& Control & 45.00 & 28.79 & 20 \\
Persian Pre-Quantifiers vs. & Total & 70.00 & 33.10 & 40 \\
English Phrasal Quantifiers & Experimental & 91.25 & 10.01 & 20 \\
Persian Compound/Post & Control & 63.12 & 17.89 & 20 \\
Quantifiers vs. English Phrasal & Total & 77.18 & 20.19 & 40 \\
Quantifiers & & & & \\
\hline
\end{tabular}

All descriptive statistics showed that there was a great difference between the performances of the subjects in the two groups in all types of the tasks in immediate post-test and the experimental group considerably got the higher scores in five contexts compared to the control group in two tasks. A comparison of the means scores is presented in Tables 6 and 7.

The analysis of the results using repeated measure ANOVA revealed that in GJT (Wilks' Lambda $=0.36, \mathrm{~F}(4,35)$ $=15.55, p<0.05)$ and in TT (Wilks' Lambda $=0.71, \mathrm{~F}(4,35)=3.57, p=.015)$ there was a significant difference among the five contexts. Also, there was a significant difference between the groups in both tasks, in GJT $\left\{\mathrm{F}_{(1,38)}\right.$ $=124.23, p=.00$, Partial Eta Squared $=.76\}$ and in $\mathrm{TT}\left\{\mathrm{F}_{(1,38)}=294.97, p=.00\right.$, Partial Eta Squared $\left.=.88\right\}$ and 
consequently, the experimental group outperformed the control group in all the contexts. These results suggest that the experimental group learn that English quantifiers better and negative evidence has a considerable amount of effect on learning English quantifiers. Moreover, this indicates that similarity and dissimilarity between structures of the two languages did not have a considerable effect on English quantifies by the experimental group receiving negative evidence.

\subsection{Delayed Post-Test Scores}

To see the long-term effects of the instruction on learners' perception and production of English quantifiers the delayed post-test was administrated.

Table 8. Descriptive statistics of delayed post-test in GJT for both groups

\begin{tabular}{llccc}
\hline & Group & Mean & Std. Deviation & N \\
\hline \multirow{2}{*}{ Persian and English Simple } & Experimental & 71.66 & 16.31 & 20 \\
Pre-Quantifiers & Control & 42.50 & 10.43 & 20 \\
& Total & 57.08 & 20.02 & 40 \\
Persian Simple Post-Quantifiers & Experimental & 88.12 & 11.80 & 20 \\
vs. English Simple & Control & 67.50 & 15.38 & 20 \\
Pre-Quantifiers & Total & 77.81 & 17.09 & 40 \\
Persian Compound Quantifiers & Experimental & 71.25 & 15.75 & 20 \\
vs. English Simple & Control & 36.87 & 13.12 & 20 \\
Pre-Quantifiers & Total & 54.06 & 22.53 & 40 \\
& Experimental & 76.87 & 14.20 & 20 \\
Persian Pre-Quantifiers vs. & Control & 51.87 & 12.35 & 20 \\
English Phrasal Quantifiers & Total & 64.37 & 18.24 & 40 \\
& Experimental & 75.93 & 8.42 & 20 \\
Persian Compound/Post & Control & 45.62 & 13.31 & 20 \\
Quantifiers vs. English Phrasal & Total & 60.78 & 18.88 & 40 \\
Quantifiers & & & & \\
\hline
\end{tabular}

Table 9. Descriptive statistics of delayed post-test in TT for both groups

\begin{tabular}{llccc}
\hline & Group & Mean & Std. Deviation & N \\
\hline \multirow{2}{*}{ Persian and English Simple } & Experimental & 81.66 & 16.13 & 20 \\
Pre-Quantifiers & Control & 45.00 & 22.36 & 20 \\
& Total & 63.33 & 26.74 & 40 \\
Persian Simple Post-Quantifiers & Experimental & 90.00 & 17.01 & 20 \\
vs. English Simple & Control & 58.75 & 12.23 & 20 \\
Pre-Quantifiers & Total & 74.37 & 21.54 & 40 \\
Persian Compound Quantifiers & Experimental & 70.00 & 19.19 & 20 \\
vs. English Simple & Control & 31.25 & 24.16 & 20 \\
Pre-Quantifiers & Total & 50.62 & 29.13 & 40 \\
& Experimental & 91.25 & 12.23 & 20 \\
Persian Pre-Quantifiers vs. & Control & 31.25 & 27.95 & 20 \\
English Phrasal Quantifiers & Total & 61.25 & 37.10 & 40 \\
& Experimental & 86.25 & 10.65 & 20 \\
Persian Compound/Post & Control & 61.25 & 15.12 & 20 \\
Quantifiers vs. English Phrasal & Total & 73.75 & 18.08 & 40 \\
Quantifiers & & & &
\end{tabular}


However, there was a slight demotion in the performance of both groups, descriptive statistics such as total means and standard deviations of the five contexts in both groups revealed that there was a great difference in the performance of the subjects in both groups in all types of the tasks and the experimental group outperformed the control group, similar to the first post-test. Tables 8 and 9 represent the mean performance of two groups of participants on the Grammaticality Judgment Task (GJT) and Translation Test (TT) in the five contexts.

The inferential analysis of the results using repeated measure design showed that there was a statistically significant difference between the five contexts in both in GJT (Wilks' Lambda $=0.37, \mathrm{~F}(4,35)=14.89, p<0.05$ ) and TT (Wilks' Lambda $=0.46, \mathrm{~F}(4,35)=9.92, p<0.05$ ). Ultimately, The data were further analysed to find out if there was any difference between the two groups in the delayed post of both tasks and the results revealed that there was a statistically significant difference between the groups in GJT $\left(\mathrm{F}_{(1,38)}=157.59, p=.00\right.$, Partial Eta Squared $=.80)$ and in TT $\left(\mathrm{F}_{(1,38)}=346.04, p=.00\right.$, Partial Eta Squared $\left.=.90\right)$. Concerning the long-term effect of the explicit input on learning English quantifiers, again the effect of negative evidence exceeded that of the positive evidence in the delayed post-test. The difference, similar to the immediate post-test, was significant $(\mathrm{p}<0.05)$.

\section{Discussion and Conclusion}

The aim of the study was to examine the effects of positive and negative evidence in short-term and long-term period in the acquisition of English quantifiers by Iranian EFL. As it will be mentioned earlier there are a large number of quantifiers in English and Persian. But in this study thirteen English quantifiers (some, no, any, none of, a large number of, a large amount of, much, many, too much, too many, a few, a little and a lot of) were under the investigation and based on the translation of them into Persian five contexts were revealed. Context one is similar in two languages but other four contexts are dissimilar in both languages. This means that in context one "Persian and English simple pre-quantifiers" both structures are pre-quantifiers but in other four contexts (context two "Persian Simple post- quantifiers vs. English simple pre-quantifiers", context three "Persian Compound Quantifiers vs. English Simple Pre-Quantifiers", context four "Persian Pre Quantifiers vs. English Phrasal Quantifiers", context five "Persian Compound/Post Quantifiers vs. English Phrasal Quantifiers") both structures are dissimilar in two languages. Given the above five contexts, the current study endeavored to investigate whether similarities and dissimilarities between the structures of two languages can affect the acquisition of English quantifiers. In this way, the role of L1 structures in the acquisition of English quantifiers constituted another purpose of the study. The findings of this study permit the following responses to the research hypotheses under investigation:

1) There is no relationship between positive and negative input in the acquisition of English quantifiers by Iranian EFL learners.

To conclude, the data from the present study demonstrate that negative evidence was highly effective in learning English as a foreign language by Persian students in short-term and long-term period. The evidence for this conclusion came from the immediate and delayed post-tests. In fact, in the test right after and even after two weeks as an interval, the participants in the experimental group who were taught through negative evidence outperformed the participants in the control group. The control group had been taught the same structure merely through positive evidence. Thus, this conclusion rejects the first hypothesis investigated in this study.

2) There is no difference between positive and negative input in short and long-term period.

Although the mean differences between the performances of the subjects in the two groups reduced over time, the two groups exhibited asymmetrical performance similar to the results obtained in the immediate post-test. In other words, the experimental group showed a significantly different performance compared to the control group. This means that the second part of the hypothesis can be rejected by the findings.

3) There is no difference between positive and negative input in the acquisition of English quantifiers through Persian and English simple pre-quantifiers.

Furthermore, the results of context one indicated that the performance of participants in both groups improved but the performance of experimental group were significantly higher than the control group and the experimental group who received the negative evidence had a better presentation. It can be claimed that similarity between the two languages may have helped the learners but the effects of negative evidence was significantly higher than L1 transfer. Consequently, the third hypothesis is rejected based on the obtained results in this context for both groups.

4) There is no difference between positive and negative input in the acquisition of English quantifiers through Persian simple post-quantifiers and English pre-quantifiers. 
5) There is no difference between positive and negative input in the acquisition of English quantifiers through Persian compound quantifiers and English simple quantifiers.

6) There is no difference between positive and negative input in the acquisition of English quantifiers through Persian pre-quantifiers and English phrasal quantifiers.

7) There is no difference between positive and negative input in the acquisition of English quantifiers through Persian compound/post quantifiers and English phrasal quantifiers.

In the other four contexts, both groups had an improvement, but the experimental group in all the contexts outperformed the control group. It seems that, dissimilarity between the two languages did not hinder the acquisition of English quantifiers and the effect of negative evidence was significantly higher than L1 transfer. Thus the fourth, fifth, sixth and seventh hypothesis are rejected based on the obtained results in these contexts for both groups. In sum, the investigation of five contexts indicated that the negative evidence causes better understanding/learning of quantifiers in the experimental group, who received negative input than the control group, who received positive input.

As results showed, negative evidence facilitates and enhances the phase of the acquisition of the foreign language, namely English quantifiers in the absence of naturalistic input and negative evidence can support the permanent mastery of the grammar of quantifiers.

Additionally, the findings of the current study are consisted with White (1988). She states that positive evidence alone is not sufficient. Concerning whether or not L2 acquisition can progress on the basis of positive evidence alone and she latter suggests that it cannot, and that "there will be cases where change from $\mathrm{X}$ to $\mathrm{Y}$ will require negative evidence" (p. 148). Also when an option is just permitted in the learners L1, it is necessary to use negative evidence. So negative evidence is necessary to activate the resetting of the parameter to its L2 value. The role of negative evidence adopted by the partial access position consists in providing access to properties defined by the principles learners have no longer access to.

Negative evidence provides opportunities for learners to notice different points when their message is misunderstood, which could lead to reconsiderations (Chouinard \& Clark, 2003). According to Gass (1988, 1990, 1991) negative evidence functions as an attention getting device. Latter she added that fossilization might occur if in the classrooms direct or frequent negative feedback do not practice. Since it would permit learners to detect discrepancies between their learner language and the target language. Likewise, Ellis (1994) and Long and Robinson (1998) supported the view that some forms cannot be acquired by positive evidence alone.

Task differences are shown to be a basic source of variation in L2 learner's performance (Tarone, 1979; Ellis, 1994, 2000; Rahimpour, 1995, 1997; Robinson, 1995). The findings of this study revealed that different task types lead to different performances in the learners especially through the experimental group. Consequently, learner's interlanguage is systematically variable and this variability is attributed to the task types performed by the learners.

Theoretically, this study has uncovered the effects of different kinds of linguistic input on foreign language learning in general and on the acquisition of quantifiers in particular. This study is significant in that it has examined the effect of different types of input available to language learners in an EFL environment leading to a better recognition of second language process and also to a better identification of the obstacles and difficulties that learners are involved in this process. Moreover, the findings of this study is helpful for language learning theorists in that they would be familiar with the role of these two types of input in learning English as a foreign language and they would be able to develop new theoretical ideas or even modify their previously fixed ideas.

A pedagogical implication of the present study is that the results of this study will be beneficial for curriculum planners and English language learners and instructors as well as educational administrators in Iran. It is greatly hoped that insights gained from the current study can provide invaluable information for devising appropriate materials and effective teaching techniques suitable for different groups of learners at various stages of second language development.

In spite of the attempts made in providing a comprehensive account of negative and positive evidence, this study could have been wider and more extensive dealing with different proficiency levels. Furthermore, all the data were collected and interpreted by only one author. Hence, conducting a more extensive study and examining the usefulness of negative and positive evidence in greater detail will be subject to further research.

\section{References}

Amokhteh, R. (1997). Noun prefix argument in English and Persian (Unpublished master's thesis). University of 
Tehran, Tehran.

Bley-Vroman, R. (1989). The logical problem of second language learning. In S. Gass, \& J. Schachter (Eds.), Linguistic Perspectives on Second Language Acquisition (pp. 41-68). Cambridge, UK: Cambridge University Press. http://dx.doi.org/10.1017/CBO9781139524544.005

Chomsky, N. (1968). Language and mind. New York: Harcourt Brace Jovanovich.

Chomsky, N. (1975). Reflections on Language. New York: Pantheon.

Chouinard, M. M., \& Clark, E. V. (2003). Adult reformulations of child errors as negative evidence. Journal of Child Language, 30(3), 637-669. http://dx.doi.org/10.1017/S0305000903005701

Cook, V. (1991). Second language learning and second language teaching. London: Edward Arnold.

Ellis, R. (1991). Grammar teaching practice or consciousness-raising? In R. Ellis (Ed.), Second language acquisition and second language pedagogy (pp. 232-241). Clevedon, UK: Multilingual Matters.

Ellis, R. (1994). The study of second language acquisition. Oxford: Oxford University Press.

Ellis, R. (2000). Second language acquisition. Oxford: Oxford University Press.

Gass, S. M. (1988). Second language vocabulary acquisition. Annual Review of Applied Linguistics, 9, 92-106. http://dx.doi.org/10.1017/S0267190500000829

Gass, S. M. (1990). Second and foreign language learning: Same, different or none of the above? In B. VanPatten, \& J. Lee (Eds.), Second language acquisition (pp. 34-44). Clevedon, UK: Multilingual Matters.

Gass, S. M. (1991). Grammar instruction, selective attention, and learning. In R. Phillipson, E. Kellerman, L. Selinker, M. Sharwood-Smith, \& M. Swain (Eds.), Foreign/second language pedagogy research (pp. 124-141). Clevedon, UK: Multilingual Matters.

Gass, S. M., \& Varonis, E. M. (1994). Input, interaction and second language production. Studies in Second Language Acquisition, 16, 283-302. http://dx.doi.org/10.1017/S0272263100013097

Harley, B. (1989). Functional grammar in French immersion: A classroom experiment. Applied Linguistics, 10, 331-359. http://dx.doi.org/10.1093/applin/10.3.331

Krashen, S. D. (1982). Principles and practice in second language acquisition. Oxford: Pergamon Press.

Krashen, S. D. (1985). The input hypothesis: issues and implications. New York: Longman.

Labov, W. (1969). Contraction, deletion, and inherent variability of the English copula. Language, 45, 715-762. http://dx.doi.org/10.2307/412333

Long, M. H. (1996). The role of linguistic environment in second language acquisition. In W. C. Ritchie, \& T. K. Bhatia (Eds.), Handbook of second language acquisition (pp. 413-468). San Diego: Academic Press.

Mahootian, Sh. (1997). Persian. New York: Routledge. http://dx.doi.org/10.4324/9780203192887

Murphy, R. (2012). English Grammar in Use (4th ed.). Cambridge: Cambridge University Press.

Rahimpour, M. (1995). Interlanguage variation and task performance. Paper presented at SLRF, 95 Conference at Cornell University, Ithaca, New York. 29th September-1st October, 1995.

Rahimpour, M. (1997). Task complexity, task condition and variation in L2 oral discourse (Unpublished doctoral dissertation). The University of Queensland, Brisbane, Australia.

Robinson, P. (1995). Attention, memory, and the "noticing" hypothesis. Language Learning, 45, 283-331. http://dx.doi.org/10.1111/j.1467-1770.1995.tb00441.x

Schmidt, R. (1990). The role of consciousness in second language learning. Applied Linguistics, 11, 129-158. http://dx.doi.org/10.1093/applin/11.2.129

Schmidt, R. (1995). Consciousness and foreign language learning: A tutorial on the role of attention and awareness in learning. In R. Schmidt (Ed.), Attention and awareness in foreign language learning (pp. 1-63). Honolulu: University of Hawaii Press.

Schmidt, R. (2001). Attention. In P. Robinson (Ed.), Cognition and second language acquisition (pp. 3-32). Cambridge: Cambridge University Press.

Schwartz, B. D. (1993). On explicit and negative data effecting and affecting competence and linguistic behavior. Studies in Second Language Acquisition, 15, 147-163. http://dx.doi.org/10.1017/S0272263100011931 
Shaghaghi, V. (2003). Persian Quantifiers. Journal of literature and Human Sciences (pp. 622-648). Ferdowsi University of Mashhad.

Swain, M. (1985). Communicative competence: Some roles of comprehensible input and comprehensible output it its development. In S. M. Gass, \& C. G. Madden (Eds.), Input in second language acquisition (pp. 235-253). Rowley, MA: Newbury House.

Swan, M. (2006). Practical English Usage (2th ed.). Oxford: Oxford University Press.

Tarone, E. E. (1979). Interlanguage as a chameleon. Language Learning, 29, 181-191. http://dx.doi.org/10.1111/j.1467-1770.1979.tb01058.x

Ware, R. X. (1979). Some Bits and Pieces. In F. J. Pelletier (Ed.), Mass Terms: Some Philosophical Problems (pp. 15-29). Dordrecht: D. Reidel.

White, L. (1988). Island effects in second language acquisition. In S. Flynn, \& W. O’Neil (Eds.), Linguistic Theory in Second Language Acquisition (pp. 144-172). Dordrecht: Kluwer. http://dx.doi.org/10.1007/978-94-009-2733-9_10

White, L. (1990). Implications of learnability theories for second language learning and teaching, In M. A. K. Halliday, J. Gibbons, \& H. Nicholas (Eds.), Learning, Keeping and Using Language (pp. 271-286). Amsterdam, John Benjamins.

White, L. (1991a). Adverb placement in second language acquisition: Some effects of positive and negative evidence in the classroom. Second Language Research, 7, 133-161.

White, L. (1991b). The verb-movement parameter in second language acquisition. Language Acquisition, 1, 337-360. http://dx.doi.org/10.1207/s15327817la0104_2

\section{Copyrights}

Copyright for this article is retained by the author(s), with first publication rights granted to the journal.

This is an open-access article distributed under the terms and conditions of the Creative Commons Attribution license (http://creativecommons.org/licenses/by/3.0/). 